Article

\title{
Social Support and Commitment within Social Networking Site in Tourism Experience
}

\author{
Namho Chung *, Inessa Tyan and Hee Chung Chung \\ College of Hotel \& Tourism Management, Kyung Hee University, 26 Kyunghee-daero, Dongdaemun-gu, \\ Seoul 02447, Korea; inessa-jang@hotmail.com (I.T.); junghj@khu.ac.kr (H.C.C.) \\ * Correspondence: nhchung@khu.ac.kr; Tel.: +82-2-961-2353; Fax: +82-2-961-9557
}

Received: 28 September 2017; Accepted: 10 November 2017; Published: 16 November 2017

\begin{abstract}
More and more tourists are becoming active members of social networking sites (SNS) and are tending to use SNS during different trip stages. Thus, SNS use allows their members to find a great variety of tourism information; share experiences by posting various pictures, photos, and blogs; tag photos; and read and leave comments on network friends' posts. By getting tagged in a friend's photos or getting some positive comments, the tourists using SNS can perceive social support from both friends and other network members, and obtain positive emotions triggering from maintaining relationships with family members and close friends or sharing opinions and ideas with people with similar interests. All this can change and shape the satisfaction with tourism experience of the tourists. This study aims to fill the gap in understanding the relationship between SNS use and satisfaction with tourism experience by exploring the effect of psychological factors caused by SNS use on tourists' experience. More specifically, this research attempts to investigate the mediating effects of perceived social support, positive emotions, and commitment. The statistical results show that SNS use positively affect satisfaction with tourism experience by mediating positive emotions and commitment and perceived social support, and commitment also positively influences satisfaction with tourism experience by mediating positive emotions. With these results, this study extends the research stream of tourism experience by figuring out the mediating role of positive emotions caused by SNS use. Additionally, these findings provide some practical implications regarding marketing techniques that use SNS to increase satisfaction with tourism experience of tourists.
\end{abstract}

Keywords: social networking site; broaden-and-build theory; tourism experience; smart tourism; perceived social supported; positive emotions; commitment; information sharing

\section{Introduction}

Social media are considered one of the most rapidly growing communication technologies [1-3]. Although social media is represented in a variety of forms such as photo sharing sites (e.g., Flickr), video creation and information sharing sites (e.g., YouTube), online communities, social tagging (e.g., Digg), and newsreaders (e.g., Google Reader), the most popular ones are social networking sites (SNS) (e.g., Facebook) [4-6]. The popularity of SNS can be proven by the number of people using them. According to Statista [7], an online statistical portal, the number of SNS users has grown from 2.14 billion in 2015 to 2.46 billion in 2017, and is predicted to achieve 3.02 billion by 2020. Continued interest in SNS use can be explained by the social and affective benefits users receive from SNS [8].

SNS are virtual communities that enable their members to connect and interact with other users on a particular subject and share knowledge and experiences [9]. Many researchers within information and communication technologies (ICT) and social psychology areas have begun investigating SNS use, focusing on the main reasons that influence SNS acceptance and continuous use $[8,10]$, psychological outcomes of SNS use [4,11], and major indicators of social networking [12,13]. 
Since many tourists actively use SNS to search, share, and explain their personal travel stories and experiences [14], tourism organizations and destination managers emphasize the role of SNS in contributing to understanding and responding to the tourists' preferences [15]. Thus, SNS use has emerged as a trend in smart tourism research, attracting deeper and deeper interest of more tourism and hospitality researchers $[16,17]$. Generally, tourism studies have concentrated on the role of SNS in the contexts of tourism information searches [1], sharing tourism experiences [16], tourism-related electronic word-of-mouth (eWOM) [18], and designing tourism websites [19]. However, despite of the importance of satisfaction with tourism experience in terms of positive recommendations, revisits, and additional economic and socio-psychological benefits [17], studies exploring the relationship between SNS use and satisfaction with tourism experience are scarce.

Several studies of SNS use that emphasize the role of social support $[17,20]$, illustrate that social support can play an important role in the tourism experience. Everyday, a large number of tourists share photos and videos of places they have recently visited or are visiting, write blogs and micro-blog posts to communicate with family and friends, and seek support from both people they know and strangers, without any time or space constraints [21]. Despite the obvious significance of social support in the tourism setting, very few studies have been conducted [17].

Meanwhile, several researchers have paid attention to the concept of tourists' positive emotions [22,23]. Positive emotions have been widely investigated by marketing researchers due to their crucial role in the decision making process [23,24]. In this context, the positive emotions of tourists can affect their decision making process. However, on-site experience as well as decision-making is very important for tourists who consume the experience. That is, how satisfied tourists were in a destination is more important than how they made their decisions [25]. Schmitt [26] mentioned the importance of consumers' emotions in their experience and argued that emotions have a profound effect on consumers' experience. Additionally, Mitas, Yarnal, Adams, and Ram [22] found that tourists' positive emotions change their experience during different trip stages. In this vein, although the role of tourists' positive emotions in their tourism experience is important, there is a lack of research investigating this. Therefore, this study attempts to investigate the relationship between tourists' positive emotions and satisfaction with tourism experience.

In the context of the relationship between social networking and satisfaction with tourism experience, commitment is another important factor. However, there is no evidence of the existence of a direct positive relationship between commitment to SNS and satisfaction with tourism experience. Tourists who actively participate in SNS are seen as belonging to communities and seem to be socially influenced by other community members [16]. Pühringer and Taylor [27] argue that the intended audiences of tourism blogs and SNS such as Facebook are mainly friends and family members. Thus, the tourists' desire to get social support from SNS can be well understood. By enabling members to feel social support and contact with others, SNS can also lead to tourists' experiencing positive emotions when using SNS during a trip. Wang, Park, and Fesenmaier [28] argues that the tourists who share their tourism experiences online tend to choose to participate in different activities that will lead to positive emotions, which, in turn, will influence their satisfaction with tourism experience. In a study by Kim, Fesenmaier and Johnson [29], it is also stated that the tourists' emotions may be heavily influenced by interactions with friends and others via social media. Many years ago, many researchers explored the issue of commitment in the context of organizational behavior [30]. Recently, the issue is attracting a high interest by SNS and tourism researchers $[8,16]$. Existing studies have tried to understand the reasons and motivational factors as to why people use SNS and share tourism experiences, but no study has yet investigated the role of commitment in the relationship between SNS use and satisfaction with tourism experience.

Therefore, the purpose of this study is three-fold. First, this study determines how SNS use is related to perceived social support, positive emotions, and commitment. Second, the study investigates the relationship between perceived social support and positive emotions and commitment, and the 
relationship between commitment and positive emotions. Third, the study explores how perceived social support, positive emotions, and commitment influence satisfaction with tourism experience.

\section{Theoretical Background}

\subsection{SNS Use in the Tourism Context}

Online social networks are similar to social networks in reality. In other words, SNS users can share information and enjoy special benefits related to virtual space [4,31]. The dynamic and multimodal features of SNS allow users to share, post, and discuss interests with similarly interested users without time and distance constraints [32], eventually expanding users' social circles and increasing the frequency of interpersonal contacts [18].

SNS have become an indispensable part of tourism. Using SNS, today's tourists find information about tourism products and services before a trip [33]; post and share real-time feelings [34], tourism reviews, sentiments, and personal experiences while on their trip [1]; and write stories including photos, audio and voice podcasts, and leave recommendations after taking a trip [18]. SNS have undoubtedly transformed tourists from passive consumers of tourism experiences to active co-producers of experiences engaging in peer-to-peer tourism product recommendations and electronic word-of-mouth (eWOM) [35]. These changes can be explained in perspective of smart tourism. Smart tourism means the phenomenon that ICT and tourism converge to provide more freely customized information to tourists, and numerous researchers conceptualize and define smart tourism. For instance, Gretzel, Sigala, Xiang, and Koo [36] defined smart tourism as "tourism supported by integrated efforts at, a destination to collect and aggregate/harness data derived from physical infrastructure, social connections, government/organizational source and human bodies/minds in combination with the use of advanced technologies to transform that data into on-site experiences and business value-propositions with a clear focus on efficiency, sustainability and experience enrichment" (p. 181). Therefore, the tourism behavior changed by the ICT mentioned above is one characteristic that can be seen in smart tourism.

The emerging popularity of SNS use among a large number of tourists has triggered a great interest by tourism researchers. On the one hand, most studies have focused on the use of SNS for tourism information searches. For example, Xiang and Gretzel [1] examined the role of social media as a source of online tourism information and found that SNS were not yet the major source for tourism information. Other studies have paid special attention to trust in SNS in terms of tourism information, suggesting that user's trust in tourism websites varies significantly $[37,38]$.

Meanwhile, tourism studies have also considered the use of SNS in terms of user characteristics and motivations for sharing. Kang and Schuett [16] provided several important implications for tourism marketers investigating why the tourists share tourism experience through SNS by examining commitment and perceived enjoyment. Earlier studies have found three functional motives for sharing tourism information via SNS are obtaining tourism information, distributing tourism information, and recording tourism experiences [21].

These studies have focused on how tourists use SNS during a trip. However, various psychological factors caused by the use of SNS can affect their satisfaction with tourism experience. For instance, Kim and Tussyadiah [17] investigated the effect of social support received by using SNS on tourism experience and found that social support has a positive impact on tourism experience and in particular, the way of self-presentation has a moderating effect on the relationship between SNS use and social support. It can be interpreted that the psychological factors induced by the use of SNS can enhance the satisfaction with tourism experience. Kim, Lee, and Bonn [39] examined the psychological effects of SNS activities of senior tourists during their trip and found that the attachment formed by the SNS activity had significant influence on revisit intention. In similar context, Chung and Han [40] investigate the interrelationship among tourists' persuasion, attachment and behavioral changes. They found that source credibility and network externality had significant impacts on travel 
informational influence, social media normative and attachment and these variables also influence on behavioral changes. Hur, Kim, Karatepe, and Lee [41] explored the factors influencing information sharing and social media continuance usage and found that argument quality and source credibility had an impact on continuance usage intention and information sharing intention by mediating information seeking, entertainment and relationship maintenance motive. However, studies on the effects of these psychological factors are limited, and there is still a gap in the full understanding of the relationship between SNS use and satisfaction with tourism experience. To fill this gap, this study focuses on perceived social support, positive emotions, and commitment and examines how SNS use can contribute to the satisfaction with tourism experience.

\subsection{Commitment to SNS}

When individuals form an attitude toward an object within a particular organization or group, social influence can have a profound impact on this attitude formation or change. Kelman [30] explores individual's commitment (or attitude) to the object from the perspective of social influence. According to his study, three types of commitment (compliance, identification and internalization) can be formed depending on the level of social influence. Specifically, compliance can be determined "to occur when an individual accepts influence because he/she hopes to achieve a favorable reaction from another person or group" (Kelman [30], p. 53). Identification can be determined "to occur when an individual accepts influence because he/she wants to establish or maintain a satisfying self-defining relationship to another person or a group". Lastly, internalization can be determined to occur when an individual accepts influence because the content of the induced behavior is intrinsically rewarding". Meanwhile, Klein, Molloy, and Brinsfield [42] defined commitment as "a volitional psychological bond reflecting dedication to and responsibility for a particular target" (p. 137).

ICT researchers have often investigated commitment in order to explain user continuance behavior related to innovative technologies [43]. In the context of SNS use among tourists, commitment refers to both the antecedents and consequences of SNS use and the process and state of attachment to use of different types of social media [44]. Previous researchers state that volitional contributions and proactive engagement depend on the tourist's personal norms and values as well as normative social compliance. Based on previous studies it can be supposed that levels and types of volitional commitments to using SNS in different travel stages differ among tourists [44].

SNS, as one type of virtual community, enables tourists to search for tourism information and share their tourism experience. According to Chu and Choi [45], SNS users form strong social relationships within the network and these relationships affect each user. Therefore, it can be inferred that social influence has a strong impact within SNS users' network. As an active SNS user, a tourist can be socially influenced by other tourists participating in a specific SNS [16] in terms of his or her beliefs that some people want he or she to perform a particular behavior. This commitment in the context of this study can be defined as follows.

Internalization means the adoption of common self-guides for satisfying idealized goals shared with others [46]. Malhotra and Galletta [44] state that the behavior accepted through internalization is accompanied by the tourists' value and becomes a part of their personal norm. Based on the existing literature, it can be claimed that the tourists prefer using SNS because it reflects their values [16].

Identification occurs when a tourists adopts an impact because they want to constitute or retain a satisfying self-defining relationships [30]. Behavior accepted through identification is accomplished only under conditions of important of the relationship between influential agents and tourists [44]. Given this statement, it can be claimed that tourists using SNS feel a sense of belonging to a group of SNS users with whom they share tourism experiences and knowledge through SNS.

Compliance arises when tourists perceive that a social actor wants them to do a specific act and that the social actor has the ability to compensate or punish behavior. According to Malhotra and Galletta [44], a tourist will perform behavior based upon compliance only under circumstances of 
supervision by the influential agent. Therefore, participating in SNS may try to make an effort to use SNS in different travel stages because they feel pressured to do so [16].

From this perspective, several researchers have identified the role of commitment in the SNS context. Kang and Schuett [16] investigated the relationship between commitment and sharing tourism experience and found that commitment has a positive impact on sharing behavior by mediating perceived enjoyment. Zhou and Li [43] also examined the relationship between commitment and continuance use intention and found that commitment positively affect behavior intention.

Thus, it can be concluded that a tourist's commitment to SNS use can be formed by three independent dimensions as internalization or involvement led by the conformity between a tourist and SNS community values, identification or involvement based on a tourist's desire to become a member of a particular community, and compliance or instrumental involvement predicated by specific rewards a tourist can obtain using a particular SNS.

\subsection{Broaden-and-Build Theory of Positive Emotions}

Positive emotions have been investigated mostly by psychology and sociology researchers since these are believed to occupy an important place in social lives and to be directly related to the subjective well-being and quality of life [47,48]. Rosenberg [49] defined emotions as "acute, intense, and typically brief psycho-physiological changes that result from a response to a meaningful situation in one's environment" (p. 250). Later, studies introduced emotions as short-lived, powerful feelings related a specific situation or object, expect instantaneous attention, and stimulate a special behavior [50]. Previous researchers have also stated that emotions occupy individuals' awareness and directly affect behavior. For example, people feel an amusement when they hear a joke, and cannot help laughing, or sport fans feel excitement while watching the final seconds of a game and cheer their team [51].

The broaden-and-build theory explain positive emotions in terms of broadened though-action ranges, and describes their function related to constructing enduring personal resources. The author of the theory emphasizes that personal information accumulated while an individual is exposed to positive emotions lasts longer than temporary emotions [48]. According to this theory, when an individual experiences positive emotions, patterns of thought and behavior broaden, making him or her more open and creative [48]. Broadened thought and behavior make it easier for the individual to exploit encouraging opportunities and thereby construct valuable resources including self-knowledge, resilience, friendships, and healthy habits. In other words, positive emotions provide positive outcomes such as becoming more creative, resilient, and healthy individuals in addition to temporary emotions [48].

Fredrickson [48] focused on such positive emotions as love, joy, interest, and contentment in broaden-and-build processes. Love can be associated with strengthening existing relationships and building new ones [52]. Joy urging play behavior makes individuals more creative [50]. Interest facilitates the pursuit of novel information and experiences Contentment is akin to calm and relaxation and prompts self-reflection and savoring [53], leading to positive self-image [48].

Although some scholars have attempted to infuse greater levels of positive emotions into people's lives, studies investigating positive emotions in the context of SNS use and satisfaction with tourism experiences are very limited. Social media researchers as well as ICT studies [54] have been concentrating on perceived enjoyment which can be regarded as a positive motivation or belief, however, no one study explores positive emotions as a positive outcome of SNS use. Meanwhile, Several tourism studies have investigated positive emotions in the context of leisure travel and have confirmed the peak model that posit that positive emotions raise as travel nears [22,25]. Although it can be proposed that positive emotions can mediate the relationship between SNS use and satisfaction with tourism experience, no one study has explored this issue yet. 


\subsection{Perceived Social Support}

Cobb [55] argue that social support is information of three classes: "(1) information leading the subject to believe that he or she is cared for and loved; (2) information leading the subject to believe that he or she is esteemed and valued; (3) information leading the subject to believe that he or she belongs to a network of communication and mutual obligation (p. 300)". Based on social psychology literature, it can be stated that social support is often viewed as crucial in making social environments less stressful, healthier, and more conductive to effective adaptation to stress in one of the following ways: emotional support, instrumental support, affectionate support, informational support, and social companionship [56].

Numerous studies $[55,57]$ have shown that there are psychological social support and non-psychological support. Non-psychological support (or tangible support) signifies the providing of material support. Meanwhile, psychological support refers to emotional or cognitive support. More specifically, according to Sherbourne and Stewart [58], this psychological support can be divided into three; emotional support, instrumental support, informational support, and affectionate support.

Recent studies emphasize that social support is one of the significant benefits that SNS users perceive in online social relationships [20]. With the emergence of SNS the boundary of social support has expanded from traditional face-to-face communication context to computer-mediated communication context [17]. Previous researchers have discovered that SNS can ease social interactions and social support [11]. Since SNS can eliminate time and distance limits and draw more participants in comparison with traditional face-to-face communication networks, SNS may significantly enhance existing forms of social support [56]. In other words, when an SNS user shares his or her satisfaction with tourism experience and another user gives feedback such as a like or commenting on the post, the first user may feel social support within SNS. This feedback of SNS can have both non-psychological and psychological forms. That is, the users can directly confirm that they have received feedback, and, in the case of comments, they can feel the emotional support expressed by another user because the comment may contain elements of others' feelings. Consequently, there are a functions expressing social support in SNS.

In the context of our study, perceived social support can be defined as a tourist's beliefs about the availability of various types of support from his or her network of friends [59]. For example, if a tourist has a large number of online friends on SNS, he or she may identify some friends whom he or she would be able to rely on when facing difficulties or problems [17], or some friends with whom he or she would be like to share a positive experience and receive emotional support.

In the tourism context, social support is known to have a moderating impact on the relationship between stressful tourism experiences and psychological outcomes. Tourists can receive social support from either weak ties, such as other tourists [60] or close ties, such as those with family and friends [61]. Close ties can provide a tourist with a sense of place, while weak ties can provide the information necessary for reducing fears and risks about an unknown destination and give advices related to the preparation for a trip [17]. By sharing tourism information and following the advice of social network friends, tourists might change the plans and select other tourism activities that will change the tourist's experience with destination [28]. Thus, the social support the tourists perceive while using SNS has a meaningful influence on the satisfaction with tourism experience.

\subsection{Satisfaction with Tourism Experience}

The most important part of tourism is to develop and convey the tourist to enjoy the various cultures, where visitors can see what they want at the tourist destination [62]. It can be supposed that within tourism literature, there are both academic and commercial concerns about the nature of tourism experience [63]. This concern can be explained by an understanding of the relationship between tourism experience and its outcomes that affect the whole tourism industry. Satisfaction with tourism experience significantly influences the tourists' revisit intention and positive word of mouth that lead to economic gains for destination managers and socio-psychological benefits for tourists 
themselves [64]. Hence, satisfaction with tourism experience is acknowledged as a prominent issue for both public tourism organizations and destination marketing organizations and academic scholars in terms of investigating the main construct of tourism experience and important factors that can enhance the consumed tourism experience [17].

There many tourism-experience-related studies. Some of them attempt to conceptualize the tourism experience while others focus on experience behaviors and types of experience $[63,64]$. With the emergence of different innovative technologies and growing popularity of social media use among tourists, more and more researchers are paying attention to the technology-enhanced tourism experience [65]. Gretzel and Jamal [66] shed light on the understanding of tourism experiences and argue that technology-mediated tourism experiences are expected to be more abundant, more partaking, and facilitated via different media. Binkhorst and Den Dekker [67] emphasize the role of Internet and virtual worlds in the formation of tourism experiences, and several researchers investigate the influence of social media in tourism experiences $[17,29]$. However, the studies discussing satisfaction with tourism experiences and the influence of technology and researching technology-enhanced tourism experiences are still limited [65].

Undoubtedly, rapid development of various ICT is changed tourism globally by transforming it to be tightly related to ordinary everyday life and significantly impacting the satisfaction with tourism experience. Satisfaction with tourism experiences can be regarded as an integration of the interaction and reflection among tourists themselves, places they visit, other tourists, and social networks [68]. It has been argued in previous studies that the tourism experience is determined by the viewpoint of the tourists based on the activities and locations of the society to which they belong. Lewis, Pea and Rosen [69] point out that tourists' use of social media intensely changes how tourists see and experience the tourist destination. Through experiences shared by tourists, other social media users can experience the space and time presented by previous tourists [69]. Since the tourists can expand the time-space boundary using ICT, the dynamics of ICT open an entire new set of experiences for them [17]. Hence, SNS use among tourists can generate a better and more enjoyable tourism experience by stimulating social support [70] and positive emotions. Therefore, this study attempts to examine the effect of psychological benefits caused by sharing satisfaction with tourism experience with SNS.

\section{Research Model and Hypotheses}

This study mainly investigates the relationship between SNS use and satisfaction with tourism experience. In addition, the research explores whether the relationship between SNS use and satisfaction with tourism experience is mediated by perceived social support, positive emotions, and commitment. This study views commitment as a second-order formative factor comprising of three dimensions: identification, internalization, and compliance. Further, this research examines how perceived social support is related to both positive emotions and commitment, and investigates how commitment influences positive emotion. Finally, the research examines whether there are direct relationships between perceived social support, positive emotions and satisfaction with tourism experience. Considering the previous literature, we conceptualize the research model of this study in Figure 1. 


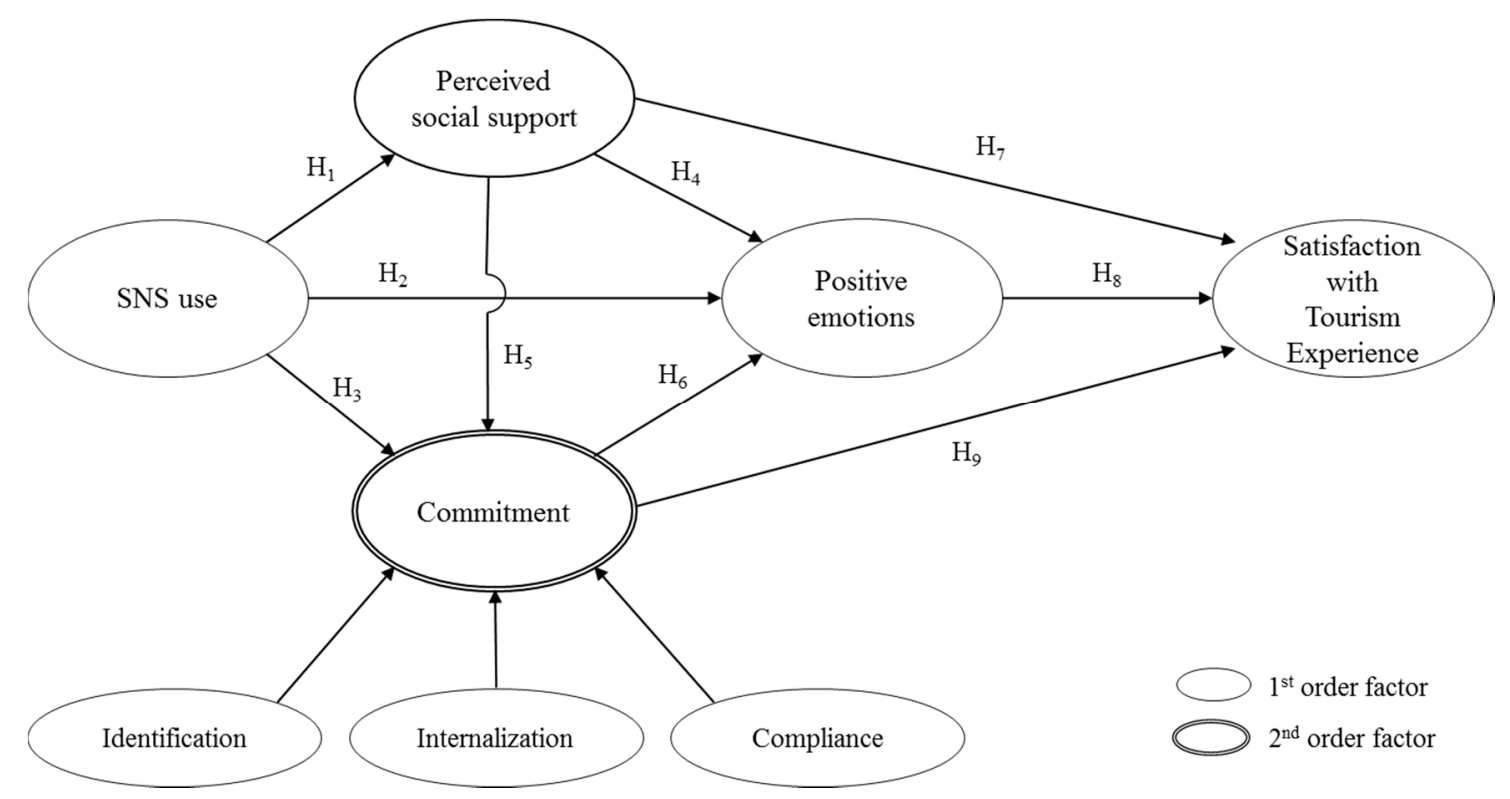

Figure 1. Research model.

\subsection{SNS Use}

SNS can significantly facilitate social interactions and social support [11]. Researchers investigating Facebook use have proven that the social network efficiently expedites the ability to demand emotional support from both strong and weak ties and support acts of social grooming [71]. Other previous studies have also found that participating in an online community can provide useful information and emotional support [56]. Kim and Tussyadiah [17] state that SNS communication consists of interactions between users and their SNS friends, in which one friend directly identifies another. It can be assumed that the users often feel social support when some of their friends tag photos with them, like their comments and photos, and leave positive comments [11]. A recent report has revealed that in comparison with general Internet users SNS users perceive greater levels of emotional support and companionship [72]. In the context of tourism, a previous study has confirmed there is a positive relationship between a tourist's SNS use and perceived social support [17]. It can be claimed that the more tourists use SNS during different trip stages, the more social support they perceive. Thus, this study states the following hypothesis:

Hypothesis (H1). A tourist's SNS use is positively related to social support a tourist perceives when using a SNS.

According to Wang and Fesenmaier [73], tourists acquire positive emotions from the use of social media when organizing and taking trips. The previous researchers also view hedonic benefits as the most important factor determining the tourist's participation in SNS [74]. It was found in previous studies that the level of participation in an online community significantly relies on hedonic benefits, which an individual's believes he or she can gain via use of SNS [75]. A recent study on emotions, brand relationship quality, and WOM has shown that social media use has a direct positive effect on visitors' emotional attachment to a festival [76]. Many researchers exploring social media use intentions emphasize the aspect of pleasure-oriented information systems and place enjoyment as the key motivational factor influencing an individual's continuous use of social media [54,77]. Based on existing literature, it can be posited that SNS use leads to the positive emotions of the tourists when dealing with SNS during a trip. Thus, the study posits the following:

Hypothesis (H2). A tourist's SNS use is positively related to the positive emotions a tourist gains when using a SNS. 
While investigating the hedonic benefits of social media use, the researchers have also paid attention to the psychological and social benefits users can obtain from social networking. Psychological and social benefits imply communication with other users, building and retaining social network, mutual interchange of opinions and experiences, and the individuals' involvement in the interchange of knowledge [78]. Previous studies have found that tourists link psychological benefits to individuals' trust in social media, to fitting in social network, and ultimately to being part of them [79]. A study by Parra-López, Bulchand-Gidumal, Gutiérrez-Taño, and Díaz-Armas [74] emphasized that tourists participating in collaborative environments by expressing opinions and sharing tourist experiences feel proud of doing so. The researchers also found that the feeling of belonging to a group it is very important to tourists who use social. In addition, Baker and White [80] stress the fact that many individuals use and intend to continuously use SNS because they feel that a lot of their friends use SNS and anticipate more friends joining SNS in the near future. Based on previous studies, it can be predicted that a tourist' SNS use directly leads to commitment to SNS, and thus this study proposes the following hypothesis:

Hypothesis (H3). A tourist's SNS use is positively related to a tourist's commitment to SNS.

\subsection{Perceived Social Support}

Positive results from social support are described as psychological rather than physical in numerous literature related to social support [81]. Psychological life satisfaction is the most active researched topic [4]. Life satisfaction can be seen as the overall evaluation of one's environment including family, work, tourism, leisure activities, and health [82]. Studies describing the relationship between the perceived social support and the quality of social network state that intercommunication within a network has positive results $[17,83]$. Several researchers have found that positive effect is closely related to social support and is a key predictor of life satisfaction, or as a intermediary that transfers the impact of social support to healthy behavior and life satisfaction [84]. Finally, Oh, Ozkaya, and LaRose [4] also have confirmed that perceived social support have a positive impact on life satisfaction. As provided in the theoretical background, positive emotions are directly associated with life satisfaction and subjective well-being. Based on the previous studies, it can be posited that if perceived social support is positively related to life satisfaction which is positively influenced by positive emotions, there will be a positive relationship between perceived social support and positive emotions. Thus, this study hypothesizes the following:

Hypothesis (H4). Perceived social support is positively related to a tourist's positive emotions.

Oh, Ozkaya, and LaRose [4] state that a sense of community is the one of the salient psychological outcome from perceived social support. A number of researchers have identified the causal relationship between sense of community and SNS use, and the results of these studies are inconsistent. More specifically, some researchers claim that SNS users who often update their profile feel a greater sense of connection with other members than those who do not [85]. Other studies have found that Facebook intensity has a negatively impact on sense of belonging [86]. A study by Oh, Ozkaya, and LaRose [4] has revealed that perceived social support from online relationship is positively related to sense of community. Based on the upper-mentioned studies, we claim that there is positive relationship between perceived social support and commitment to a SNS and posit the following hypothesis:

Hypothesis (H5). Perceived social support is positively related to a tourist's commitment to SNS.

\subsection{Commitment}

Sense of community has been investigated as one of the important factors of psychological well-being of people within offline social networks [87]. Many studies have revealed that sense of community is a crucial predictor of life satisfaction [88]. The study by Oh, Ozkaya, and LaRose [4] 
also has confirmed that sense of community positively influences life satisfaction. Several studies investigating the relationships between commitment and perceived enjoyment have found that in terms of tourism-experience sharing, identification and internalizations have positive influence on perceived enjoyment, while compliance has a negative influence on positive enjoyment [16]. In addition, based on the discussions in the previous sections, it can be supposed that the tourists are committed to SNS because many of their family members and friends use SNS. Tourists can maintain their relationships, and, thus, obtain an emotional support via SNS that can be viewed as positive emotions (love and interest). Thus, this study posits that there is positive relationship between commitment and positive emotions:

\section{Hypothesis (H6). Commitment is positively related to a tourist's positive emotions.}

\subsection{Satisfaction with Tourism Experience}

Kim and Tussyadiah [17] state that via various self-presentation activities, tourists can reflect on their tourisms, share tourism experiences, and form a sense of self through social support. Tourists used to consider tour guides, local residents, and other tourists as providers of social support [60]. However, today, with ICT development and SNS use, the tourists can seek social support not just from other tourists at their destination, but also from friends and family while taking a trip or after returning [17]. Another study has shown than SNS users can emotionally benefit from self-affirmation via social support [89]. This was confirmed by Tussyadiah and Fesenmaier [70], positing that positive feedback and social support for tourists' tourism posting or photo sharing may generate a satisfaction with tourism experience. In addition, the study by Kim and Tussyadiah [17] found that received social support as well as perceived social support positively influence satisfaction with tourism experience. The researchers state that people who follow their friends' journeys on SNS might indirectly experience the tourism, and, simultaneously, influence their experience by providing them social support. Based on the results of previous study, it can be claimed that online social support plays an important role in shaping tourist's experiences [17]. We state the following hypothesis:

Hypothesis (H7). Perceived social support has a positive influence on satisfaction with tourism experience.

Tourist satisfaction can be explained as a reflection of sensory, emotional, cognitive, behavioral, and social outcomes [26]. Kim, Fesenmaier and Johnson [29] emphasize that emotions play an essential role in constructing tourism experiences. A number of researchers consider the tourists' emotions a key feature of tourism experiences, satisfactions, and behavioral intentions [90]. Clore and Huntsinger [91] state that people make a positive evaluation based on their emotions when people feel positive emotions because they tend to use emotion at a specific point in time when the person who made the evaluation is experienced as a reference point. According to the study by Kim, Fesenmaier and Johnson [29], social media offer salient emotional clues that enable tourists to make or remake meaningful tourism experiences. Thus, it can be argued that the tourists contacting and communicating with close friends or family members via SNS can obtain positive emotions that will lead to satisfaction with tourism experience. The study proposes the following hypothesis:

Hypothesis (H8). Positive emotions a tourist obtains when using a SNS positively influence satisfaction with tourism experience.

It was acknowledged that joy through tourism experience occurs not only in seeing exotic scenery in new places, but also when experiencing it [92]. SNS enable tourists to easily exchange photos and opinions about the places they visit, and immediately share their satisfaction with tourism experiences [1]. Previous studies have paid special attention to why tourists share satisfaction with tourism experience through social media and have found the positive relationship between commitment and actual tourism-experience sharing behavior mediated by perceived enjoyment [16]. Specifically, the study by Kang and Schuett [16] have revealed that perceived enjoyment is an important consequence of social influence that significantly motivates tourism-experience sharing behavior. It can 
be supposed that the more committed tourists will be more likely to share their satisfaction with tourism experiences via SNS. Kozinets [93] states that, as time passed, the relationship among members became more intimate within the tourism community and they become more willing to spend time sharing their opinions. Based on the previous studies, we posit that tourists sharing satisfaction with tourism experiences through SNS with other members will enjoy the process, which will positively influences the overall satisfaction with tourism experience. Thus, this study proposes the following hypothesis:

Hypothesis (H9). A tourist's commitment to SNS has a positive influence on satisfaction with tourism experience.

\section{Research Methodology}

\subsection{Instrument Development}

All measurement items for our study were adapted from previous studies. SNS use items were measured based on Pagani, Hofacker, and Goldsmith [94]. Perceived social support items were adapted from Kim and Tussyadiah [17]. Positive emotions items were adapted from Venkatesh [95] and $\mathrm{Hsu}$ and Lin [96]. Identification, internalization and compliance, which are reflective factors of commitment, were adapted from Lim, Cha, Park, Lee, and Kim [97]. Finally, items from Kim, Fesenmaier and Johnson [29] and Tussyadiah and Zach [98] were adapted to measure satisfaction with tourism experience. All 23 measurement items is summarized by the constructs in Table 1, including SNS use (two items), perceived social support (three items), positive emotions (three items), commitment (twelve items), and satisfaction with tourism experience (three items).

Table 1. Constructs and Items.

\begin{tabular}{|c|c|c|c|}
\hline \multicolumn{3}{|c|}{ Constructs } & Items \\
\hline \multirow{2}{*}{\multicolumn{2}{|c|}{ SNS use }} & USE1 & $\begin{array}{l}\text { I spent time browsing travel information and tourism experiences shared } \\
\text { by others in the SNS. }\end{array}$ \\
\hline & & USE2 & $\begin{array}{l}\text { I spent time sharing travel information and my own tourism experiences in } \\
\text { the SNS. }\end{array}$ \\
\hline \multirow{4}{*}{\multicolumn{2}{|c|}{ Perceived social support }} & SUP1 & I can count on the SNS friends for helping me understand things. \\
\hline & & SUP2 & I do not feel alone because I have SNS friends. \\
\hline & & SUP3 & I think I can count on the SNS friends for helping me doing something. \\
\hline & & SUP4 & I think I can count on the SNS friends for helping me with my questions. \\
\hline \multirow{3}{*}{\multicolumn{2}{|c|}{ Positive emotions }} & EMO1 & I find using the SNS to be enjoyable. \\
\hline & & EMO2 & The actual process of using the SNS is pleasant. \\
\hline & & EMO3 & I have fun using the SNS. \\
\hline \multirow{3}{*}{\multicolumn{2}{|c|}{ Identification }} & IDN1 & $\begin{array}{l}\text { In general, I am very interested in what the SNS group members think } \\
\text { about sharing my knowledge and information through social media. }\end{array}$ \\
\hline & & IDN2 & $\begin{array}{l}\text { I feel a sense of belonging to the SNS group when I share my knowledge } \\
\text { and information through SNS. }\end{array}$ \\
\hline & & IDN3 & I feel I will fit into the SNS group when I share my knowledge through SNS. \\
\hline \multirow{6}{*}{ Commitment } & \multirow{3}{*}{ Internalization } & INT1 & $\begin{array}{l}\text { The reason I prefer use of SNS is primarily based on the similarity of my } \\
\text { values and those represented by the SNS. }\end{array}$ \\
\hline & & INT2 & $\begin{array}{l}\text { The reason I prefer SNS to other communication tools is because of } \\
\text { its value. }\end{array}$ \\
\hline & & INT3 & What the use of the system stands for is important for me. \\
\hline & \multirow{3}{*}{ Compliance } & CPL1 & $\begin{array}{l}\text { Unless I am rewarded for sharing knowledge and information on SNS in } \\
\text { some way, I may spend less time to share knowledge and information. }\end{array}$ \\
\hline & & CPL2 & How hard I work on SNS is directly related to how much I am rewarded. \\
\hline & & CPL3 & $\begin{array}{l}\text { In order for me to get the responses I want on SNS, it is necessary to } \\
\text { express the right behavior or attitude on social media. }\end{array}$ \\
\hline \multirow{3}{*}{\multicolumn{2}{|c|}{ Satisfaction with tourism experience }} & EXP1 & My overall evaluation on the most recent destination experience is positive. \\
\hline & & EXP2 & My overall evaluation on the most recent tourism experience is favorable. \\
\hline & & EXP3 & I am satisfied with the most recent tourism experience. \\
\hline
\end{tabular}


In the present study, we operationalized commitment as a second-order reflective construct indicating the motivation for a tourist to embrace and use new technology in the context of tourism. We model the construct of commitment as a function of three dimensions-identification, internalization, and compliance-based on Kelman [99]. All of the items were measured on a 7-point Likert scale ranging from strongly disagree (1) to strongly agree (7).

\subsection{Data Collection}

To test the research model, an online survey was conducted among Korean tourists who use SNS. Data were collected during the one-week period of 4-12 May 2015 among people using a particular SNS. The questionnaires were distributed to 442 respondents, however, only data from the tourists using SNS for at least one year were regarded as appropriate for further analysis. Specifically, if a respondent chose "Do not use" in "What SNS do you use most often (Q1)", chose "Little use" in "How often do you use SNS? (Q2)" and did not chose "tourist information" in "Please select all the information you have used SNS to share or use in the last year", the questionnaire was ended. Finally, a sample of 387 questionnaires was used in the present study.

Table 2 shows the demographic characteristics of the respondents. There were slightly more males than females, 203 (52.5\%) and 184 (47.5\%), respectively. The 30-49-year-old age group had the largest proportion at 58.7.2\% $(n=227)$. More than half of the respondents $(n=214 / 55.3 \%)$ were university students or holders of a university degree. The proportion of married $(n=265 / 68.5 \%)$ was higher than the proportion of single and no answer people $(n=122 / 31.5 \%)$. Among the respondents, office workers had the greatest number $(n=93 / 24.0 \%)$, followed by those working in the service industry $(n=73 / 18.9 \%)$ and homemakers $(n=71 / 18.3 \%)$. Related to monthly income, the largest group $(n=92 / 23.8 \%)$ had an average monthly income of 2-2.9 million Korean won, whereas the second largest group ( $n=83 / 21.4 \%)$ had an income of $4-4.9$ million Korean won per month; 1100 Korean won equals US $\$ 1$. The majority of the respondents $(n=156 / 40.3 \%)$ answered they use SNS from one to five times per day; and 145 (37.5\%) of the respondents used SNS over $30 \mathrm{~min}$ and less than one hour per day.

Table 2. Demographic Characteristics.

\begin{tabular}{cccc}
\hline \multirow{2}{*}{ Characteristics } & Frequency & $\%$ \\
\hline \multirow{2}{*}{ Gender } & Male & 203 & 52.5 \\
& Female & 184 & 47.5 \\
\hline \multirow{3}{*}{ Age } & $19-29$ & 51 & 13.2 \\
& $30-39$ & 121 & 31.3 \\
& $40-49$ & 106 & 27.4 \\
\multirow{3}{*}{ Education } & $50-59$ & 69 & 17.8 \\
& Over 60 & 40 & 10.3 \\
\hline \multirow{3}{*}{ Marital Status } & Middle and high school & 71 & 18.3 \\
& Two-year college & 73 & 18.9 \\
& University & 214 & 55.3 \\
& Graduate school & 29 & 7.5 \\
\hline \multirow{3}{*}{ Occupation } & Married & 265 & 68.5 \\
& Single & 120 & 31.0 \\
& No answer & 2 & 0.5 \\
\hline & Student & 41 & 10.6 \\
& Office worker & 93 & 24.0 \\
& Services & 73 & 18.9 \\
& Technician & 49 & 12.7 \\
& Professional & 24 & 6.2 \\
& Civil servant & 6 & 1.6 \\
& Businessman & 22 & 5.7 \\
& Homemaker & 71 & 18.3 \\
& Other & 5 & 1.3 \\
\hline
\end{tabular}


Table 2. Cont.

\begin{tabular}{|c|c|c|c|}
\hline \multicolumn{2}{|c|}{ Characteristics } & Frequency & $\%$ \\
\hline \multirow{6}{*}{ Monthly Income } & Less than 1 million won * & 22 & 5.7 \\
\hline & 1-1.9 million won & 56 & 14.5 \\
\hline & 2-2.9 million won & 92 & 23.8 \\
\hline & 3-3.9 million won & 69 & 17.8 \\
\hline & 4-4.9 million won & 83 & 21.4 \\
\hline & More than 5 million won & 65 & 16.8 \\
\hline \multirow{5}{*}{ SNS Use } & $1-2$ times per month & 12 & 3.1 \\
\hline & $1-2$ times per week & 54 & 14.0 \\
\hline & $1-5$ times per day & 156 & 40.3 \\
\hline & 5-10 times per day & 74 & 19.1 \\
\hline & Over 10 times per day & 91 & 23.5 \\
\hline \multirow{6}{*}{ Average SNS use per day } & Less than $30 \mathrm{~min}$ & 85 & 22.0 \\
\hline & Over 30 min-less than $1 \mathrm{~h}$ & 145 & 37.5 \\
\hline & Over $1 \mathrm{~h}$-less than $2 \mathrm{~h}$ & 95 & 24.5 \\
\hline & Over $2 \mathrm{~h}$-less than $3 \mathrm{~h}$ & 34 & 8.8 \\
\hline & Over $3 \mathrm{~h}$-less than $5 \mathrm{~h}$ & 19 & 4.9 \\
\hline & Over $5 \mathrm{~h}$ & 9 & 2.3 \\
\hline \multicolumn{2}{|c|}{ Total } & 387 & 100.0 \\
\hline
\end{tabular}

\section{Data Analysis and Results}

To analyze the proposed research model, we employed a partial least squares (PLS) regression analysis, which has been widely used in theory testing and confirmation. The PLS is a multivariate technique to test structural models, which estimates the model parameters minimizing the residual variance of the whole model dependent variables, does not require an parametric conditions and is appropriate for a small sample size [100]. Moreover, because of one of the variables (commitment) that constitutes this study model is the second-order formative construct, we apply the PLS technique to verify our research model. Considering the advice from previous studies, using a PLS-graph program, we undertook a two-stage methodology in data analysis including the development and evaluation of the measurement model. In addition, the structural model was assessed and the relationships between the constructs, as specified by the research model, were evaluated [101].

\subsection{Measurement Model}

This study models commitment as a second-order formative construct. To confirm the reliability and validity of the measurement model, we assessed convergent validity and discriminant validity.

As shown in Table 3, all measures are proven to be robust in terms of their reliability, since all standardized loadings are statistically significant as they are higher than minimal threshold of 0.70 [102] (see Table 4). First, Cronbach's $\alpha$ for all constructs exceeds the minimal threshold of 0.70 [103]. Furthermore, the composite reliabilities ranging from 0.85 to 0.94 also exceed the recommended threshold value of 0.70 [104]. Finally, the average variance extracted (AVE) for each construct was greater than 0.5 , varying from 0.69 to 0.85 . These results indicate that convergent validity of the measurement model was adequate. 
Table 3. Descriptive Statistics of Constructs.

\begin{tabular}{|c|c|c|c|c|c|c|}
\hline \multicolumn{2}{|c|}{ Construct } & Composite Reliability & AVE & Cronbach's $\alpha$ & Mean & STD \\
\hline \multicolumn{2}{|c|}{ SNS Use } & 0.856 & 0.749 & 0.903 & 4.152 & 1.04 \\
\hline \multicolumn{2}{|c|}{ Perceived Social Support } & 0.930 & 0.769 & 0.886 & 4.340 & 1.05 \\
\hline \multicolumn{2}{|c|}{ Positive Emotions } & 0.947 & 0.856 & 0.888 & 4.703 & 0.91 \\
\hline \multirow{3}{*}{ Commitment } & Identification & 0.930 & 0.816 & 0.882 & 4.391 & 0.98 \\
\hline & Internalization & 0.932 & 0.820 & 0.881 & 4.282 & 1.04 \\
\hline & Compliance & 0.873 & 0.697 & 0.901 & 4.183 & 1.00 \\
\hline \multicolumn{2}{|c|}{ Satisfaction with tourism experience } & 0.937 & 0.833 & 0.897 & 4.776 & 0.92 \\
\hline
\end{tabular}

Discriminant validity was assessed based on Gefen and Straub's [105] guidelines. There are two conditions under which the discriminant validity can be established: first, the correlation of the latent variable scores with the measurement items should be higher on their theoretically assigned factor than on other factors; and, second, square root of the AVE of each construct should be higher than squared correlations of other constructs [105]. Table 4 depicts the cross loadings of each construct. Table 5 shows correlations between constructs, where the diagonal elements represent the square roots of the AVEs. As can be seen in the table, the square root of each construct's AVE is greater than its correlations with any other construct. Hence, the adequate discriminant validity of the measurement model was supported.

Table 4. Cross loadings of each construct.

\begin{tabular}{|c|c|c|c|c|c|c|c|}
\hline Items & USE & SUP & IDN & INT & CPL & EMO & EXP \\
\hline USE 1 & $0.864 * *$ & $0.398^{* *}$ & $0.479^{* *}$ & $0.398^{* *}$ & $0.326^{* *}$ & $0.528 * *$ & $0.508^{* *}$ \\
\hline USE 2 & $0.867 * *$ & $0.462 * *$ & $0.441^{* *}$ & $0.466^{* *}$ & $0.413^{* *}$ & $0.447^{* *}$ & $0.385^{* *}$ \\
\hline SUP 1 & $0.434^{* *}$ & $0.809 * *$ & $0.628^{* *}$ & $0.538^{* *}$ & $0.429 * *$ & $0.558^{* *}$ & $0.492^{* *}$ \\
\hline SUP 2 & $0.431^{* *}$ & $0.859 * *$ & $0.643^{* *}$ & $0.662^{* *}$ & $0.470 * *$ & $0.493^{* *}$ & $0.425^{* *}$ \\
\hline SUP 3 & $0.429^{* *}$ & $0.923 * *$ & $0.673^{* *}$ & $0.663^{* *}$ & $0.521 * *$ & $0.537^{* *}$ & 0.442 ** \\
\hline SUP 4 & $0.447^{* *}$ & $0.912 * *$ & $0.655^{* *}$ & 0.672 ** & $0.506^{* *}$ & $0.563 * *$ & 0.470 ** \\
\hline IDN 1 & $0.505^{* *}$ & $0.631^{* *}$ & $0.882 * *$ & $0.664^{* *}$ & $0.502^{* *}$ & $0.599 * *$ & $0.503^{* *}$ \\
\hline IDN 2 & $0.484^{* *}$ & $0.691^{* *}$ & $0.923 * *$ & $0.697^{* *}$ & $0.497^{* *}$ & $0.606^{* *}$ & 0.502 ** \\
\hline IDN 3 & $0.452^{* *}$ & $0.686^{* *}$ & $0.904 * *$ & $0.684^{* *}$ & 0.510 ** & $0.606^{* *}$ & $0.521 * *$ \\
\hline INT 1 & $0.432^{* *}$ & $0.675^{* *}$ & $0.673^{* *}$ & $0.894^{* *}$ & $0.604^{* *}$ & $0.510^{* *}$ & $0.484^{* *}$ \\
\hline INT 2 & $0.451^{* *}$ & $0.627^{* *}$ & $0.661^{* *}$ & $0.913 * *$ & $0.574^{* *}$ & $0.604^{* *}$ & $0.508^{* *}$ \\
\hline INT 3 & $0.473^{* *}$ & $0.663^{* *}$ & $0.716^{* *}$ & $0.910 * *$ & $0.624^{* *}$ & $0.614^{* *}$ & $0.520 * *$ \\
\hline CPL 1 & $0.315^{* *}$ & $0.421^{* *}$ & $0.405^{* *}$ & $0.531^{* *}$ & $0.859 * *$ & $0.330^{* *}$ & $0.321^{* *}$ \\
\hline CPL 2 & $0.376^{* *}$ & $0.485^{* *}$ & $0.478^{* *}$ & $0.558^{* *}$ & $0.891 * *$ & $0.374^{* *}$ & $0.326^{* *}$ \\
\hline CPL 3 & $0.373^{* *}$ & $0.465^{* *}$ & $0.505^{* *}$ & $0.568^{* *}$ & $0.747^{* *}$ & $0.461^{* *}$ & $0.429^{* *}$ \\
\hline EMO 1 & $0.504^{* *}$ & $0.553^{* *}$ & $0.608^{* *}$ & $0.595^{* *}$ & 0.424 ** & $0.907 * *$ & $0.594^{* *}$ \\
\hline EMO 2 & $0.523^{* *}$ & $0.583 * *$ & $0.636^{* *}$ & $0.597^{* *}$ & $0.441^{* *}$ & $0.942 * *$ & 0.629 ** \\
\hline EMO 3 & $0.535^{* *}$ & $0.567^{* *}$ & $0.611^{* *}$ & $0.576^{* *}$ & $0.431^{* *}$ & $0.926 * *$ & $0.689 * *$ \\
\hline EXP 1 & $0.475^{* *}$ & $0.477^{* *}$ & $0.510^{* *}$ & $0.520 * *$ & $0.431^{* *}$ & $0.607^{* *}$ & $0.897 * *$ \\
\hline EXP 2 & $0.450^{* *}$ & $0.493^{* *}$ & $0.541^{* *}$ & $0.513^{* *}$ & $0.373^{* *}$ & $0.659 * *$ & $0.927^{* *}$ \\
\hline EXP 3 & $0.487^{* *}$ & $0.458^{* *}$ & $0.489^{* *}$ & $0.491^{* *}$ & $0.378^{* *}$ & $0.624^{* *}$ & $0.914 * *$ \\
\hline
\end{tabular}

Note: USE = SNS use; SUP = Perceived social support; IDN = Identification; INT = Internalization; CPL = Compliance; $\mathrm{EMO}=$ Positive emotions; EXP = Satisfaction with tourism experience. The diagonal letters in boldface are the cross loading of each construct. ${ }^{* *} p<0.01$. 
Table 5. Correlations among constructs.

\begin{tabular}{clllllll}
\hline Construct & USE & SUP & EMO & IDN & INT & CPL & EXP \\
\hline USE & $\mathbf{0 . 8 6 5}$ & & & & & & \\
SUP & $0.497^{* *}$ & $\mathbf{0 . 8 7 7}$ & & & & & \\
EMO & $0.560^{* *}$ & $0.610^{* *}$ & $\mathbf{0 . 9 2 5}$ & & & & \\
IDN & $0.530^{* *}$ & $0.740^{* *}$ & $0.668^{* *}$ & $\mathbf{0 . 9 0 3}$ & & & \\
INT & $0.501^{* *}$ & $0.726^{* *}$ & $0.636^{* *}$ & $0.754^{* *}$ & $\mathbf{0 . 9 0 6}$ & & \\
CPL & $0.428^{* *}$ & $0.549^{* *}$ & $0.465^{* *}$ & $0.555^{* *}$ & $0.662^{* *}$ & $\mathbf{0 . 8 3 5}$ & \\
EXP & $0.512^{* *}$ & $0.518^{* *}$ & $0.689^{* *}$ & $0.563^{* *}$ & $0.557^{* *}$ & $0.430^{* *}$ & $\mathbf{0 . 9 1 3}$
\end{tabular}

Note: The diagonal elements in boldface are the square root of the average variance extracted (AVE). ${ }^{* *} p<0.01$.

\subsection{Structural Model}

The proposed research model was examined for explanatory power and path significance using a bootstrapping technique. A nonparametric bootstrapping procedure with 500 re-samples was performed in the PLS analyses. The results are represented in Figure 2 and Table 6.

$\mathrm{H} 1, \mathrm{H} 2$, and $\mathrm{H} 3$ address the structural relationships between SNS use and perceived social support, positive emotions, and commitment. All three hypotheses are supported, revealing significant positive relationships: SNS use significantly influences the perceived social support $(\beta=0.497, p<0.001)$, positive emotions ( $\beta=0.249, p<0.001)$, and commitment $(\beta=0.228, p<0.001)$.

$\mathrm{H} 4$ and $\mathrm{H} 5$ concern the relationships between perceived social support and positive emotions and commitment. $\mathrm{H} 6$ concerns the relationship between commitment and positive emotions. $\mathrm{H} 4$ and H5 indicate that perceived social support has a positive effect on both positive emotions $(\beta=0.172$, $p<0.05)$ and commitment $(\beta=0.660, p<0.001)$. H6, in turn, demonstrates that there are positive relationships between commitment and positive emotions $(\beta=0.411, p<0.001)$. Therefore, H4, H5, and $\mathrm{H} 6$ are supported.

Finally, H7, H8, and H9 address the relationships between perceived social support, positive emotions, and commitment and satisfaction with tourism experience. Perceived social support seems not to have a significant influence on satisfaction with tourism experience ( $\beta=0.04$, non-significant), rejecting H7. However, both positive emotions $(\beta=0.526, p<0.001)$ and commitment $(\beta=0.205$, $p<0.01$ ) are shown to positively influence satisfaction with tourism experience, thus supporting $\mathrm{H} 8$ and H9. Therefore, while H7 is not supported, both H8 and H9 are supported.

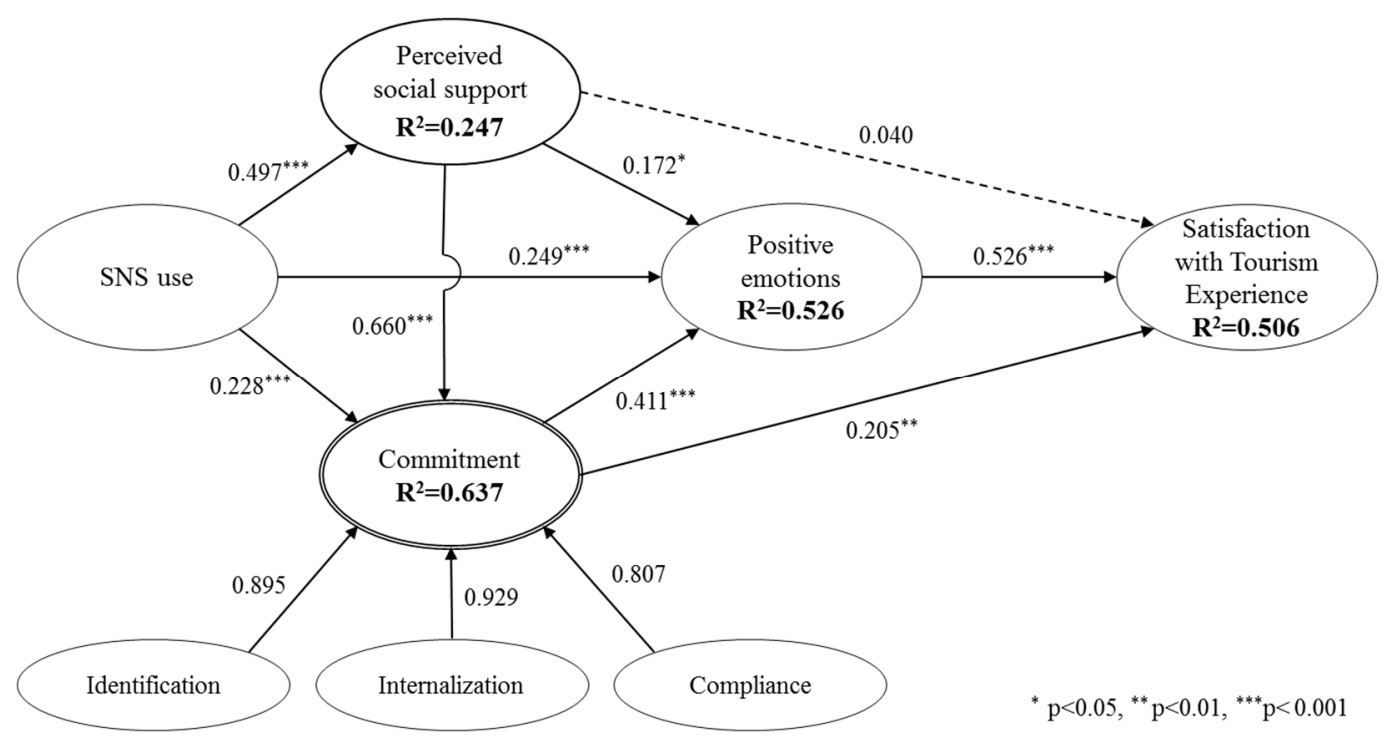

Figure 2. Structural model results. 
Table 6. Standardized Structural Estimates and Hypotheses tests.

\begin{tabular}{ccccc}
\hline Hypothesis & Path & Estimates & $t$-Value & Results \\
\hline $\mathrm{H}_{1}$ & SNS use $\rightarrow$ Perceived social support & 0.497 & 13.413 & Supported \\
$\mathrm{H}_{2}$ & SNS use $\rightarrow$ Positive emotions & 0.249 & 5.219 & Supported \\
$\mathrm{H}_{3}$ & SNS use $\rightarrow$ Commitment & 0.228 & 5.604 & Supported \\
$\mathrm{H}_{4}$ & Perceived social support $\rightarrow$ Positive emotions & 0.172 & 2.133 & Supported \\
$\mathrm{H}_{5}$ & Perceived social support $\rightarrow$ Commitment & 0.660 & 18.336 & Supported \\
$\mathrm{H}_{6}$ & Commitment $\rightarrow$ Positive emotions & 0.411 & 6.427 & Supported \\
$\mathrm{H}_{7}$ & Perceived social support $\rightarrow$ Satisfaction with tourism experience & 0.04 & 0.531 & Rejected \\
$\mathrm{H}_{8}$ & Positive emotions $\rightarrow$ Satisfaction with tourism experience & 0.526 & 9.634 & Supported \\
$\mathrm{H}_{9}$ & Commitment $\rightarrow$ Satisfaction with tourism experience & 0.205 & 2.587 & Supported \\
\hline
\end{tabular}

\section{Discussion}

This study provides further understanding as to how SNS use can have an impact on satisfaction with tourism experience. The present research focuses on the role of perceived social support, and employs the social influence theory and broaden-and-build theory of positive emotions to discover how the tourists' perceived social support using a particular SNS, commitment to the SNS, and generating positive emotions engendered by SNS use influence their satisfaction with tourism experience. The results of our study provide empirical evidence that there are significant relationships between SNS use and satisfaction with tourism experience mediated by both commitment and positive emotions.

This study has revealed that there are positive relationships between SNS use and perceived social support and commitment. These results are similar to the results of previous researchers who argue that SNS use enables its users to build strong relationships and exchange socially [106]. Specifically, Choi, Kim, Sung, and Sohn [106] measured the strength of respondents' network through questionnaires related to social capital and the number of friends connected to SNS, and found that Korean users tend to form smaller and stronger networks through SNS compared to American users. This implies that social relations can be formed through SNS. Therefore, this study supports Choi, Kim, Sung, and Sohn's [106] results by showing that SNS user can cause perceived social support and commitment. The results regarding the social support are consistent with the study by Kim, Fesenmaier and Johnson [29] supporting that tourists sharing various tourism information and tourism experiences including posting photos or blogs often seek and perceive social support from their SNS friends during different travel stages. Moreover, the positive relationships between perceived social support and commitment can be also understood. Based on the results provided by our study, we argue that developing and maintaining social relations with SNS friends and perceiving social support from them eventually lead to tourists' commitment to a specific SNS group.

The results concerned with positive emotions have found statistical relationships between SNS use and positive emotions as well as positive relationships between both perceived social support and commitment, and positive emotions. These results are consistent with prior studies that reveal that SNS use affects positive emotions such as love or satisfaction in terms of romantic relationships [107]. Moreover, studies of Facebook provide empirical evidence that Facebook use contributes to the positive emotions of its users by providing social support [108].

Furthermore, similar to prior studies, our study has found that positive emotions positively influence satisfaction with tourism experience $[109,110]$. Moreover, this study has revealed that positive emotions are the most influential determinant of satisfaction with tourism experience. Generally, in tourism studies positive emotions are confirmed to have a favorable effect on both satisfaction and behavioral intentions [111]. Since both satisfaction and positive behavioral intentions are indicators of satisfaction with tourism experience, we argue that there are significant relationships between positive emotions and satisfaction with tourism experience.

This research has also revealed the existence of positive relationships between commitment and satisfaction with tourism experience. Existing literature argues that tourists' experiences may be heavily impacted by interaction with other people and different SNS groups [29]. Hence, the results of 
our study confirm this assumption, allowing us to suppose that more committed tourists are likely to use SNS more often and communicate with their friends during different tourism stages, which will eventually lead to an enhanced satisfaction with tourism experience. Wang [92] highlights that tourism experience can be determined not only through visiting a particular tourism destination, but in sharing the memories, experiences, and knowledge obtained from this visit. Hence, several researchers try to address this matter by investigating the role of commitment on tourism experience sharing behavior revealing statistically significant relationships [16]. Our study supports the previous researchers demonstrating that commitment may greatly influence satisfaction with tourism experience.

While eight out of nine hypotheses were supported, one hypothesis that is concerned with the relationships between perceived social support and satisfaction with tourism experience was rejected. This result is different from the results of previous research [29], which revealed statistically significant direct relationships between two constructs. Our study shows that, while social support does not shape the satisfaction with tourism experience directly, it influences the satisfaction with tourism experience through positive emotions and commitment. It is obvious from the dissimilarities in the results among studies that the concept of perceived social support needs to be investigated more carefully to determine its role in the context of the relationship between SNS use and satisfaction with tourism experience.

\section{Conclusions and Future Research}

This study proposes an integrated theoretical framework by combining the social influence theory and broad-and-build theory of positive emotions to investigate whether SNS use can influence satisfaction with tourism experience. Existing literature emphasizes the role of social media and SNS use in the tourism industry in terms of the social presence's influence on tourism information search, sharing tourism information and/or satisfaction with tourism experience. The results provided by our research confirm the important role of SNS use in the tourism area and further extend existing research by providing empirical evidence that are significant relationships between SNS use and satisfaction with tourism experience. Based on the results, we can argue that although there are positive relationships between SNS use and perceived social support, positive emotions, and commitment, only positive emotions and commitment are proven to have a statistically significant impact on satisfaction with tourism experience. It can also be underscored that both commitment and positive emotions are mediators in the relationship between SNS use and satisfaction with tourism experience as well as in the relationship between perceived social support and satisfaction with tourism experience. Moreover, the results have found that positive emotions are the most influential determinant of satisfaction with tourism experience, thus emphasizing the role of broaden-and-build theory of positive emotions in the context of our study.

Our study brings in several theoretical and practical implications for both academics and practitioners. First, the results of the present research contribute to the understanding of the essence of the role of SNS use in the tourism industry highlighting that SNS use significantly impacts satisfaction with tourism experience. Second, our research framework can provide an important contribution to the comprehension of the relationship between SNS use and satisfaction with tourism experience from the perspective of positive emotions and commitment since this research is one of the few that tackles this specific matter, employing social influence theory and broaden-and-build theory of positive emotions. Finally, the results accentuate the role of positive emotions in the context of the relationship between SNS use and satisfaction with tourism experience. From this point of view, our study extends the existing marketing, social commerce, and tourism studies that focused only on the role of positive emotions in experiential decisions [23], and behavioral intentions [112], or tried to assess the positive emotions of leisure tourists [22].

Furthermore, tourism marketers and SNS managers can obtain practical implications from the results of the given research. Since the importance of SNS use in satisfaction with tourism experience is evident, destination marketers should encourage tourist to share their satisfaction with tourism 
experience and support others' experience and to have a positive perception of the destination. In other words, tourists can positively perceive destination related their experiences because they can feel psychological benefits by sharing their satisfaction with tourism experience. Additionally, sharing the satisfaction with tourism experience enhances the activation of SNS, so that SNS managers can also simulates SNS by inducing tourists to share their satisfaction with tourism experience and support other tourists.

Despite the important theoretical and practical implications, this study has some limitations as well. First, the generalizing of the results is dubious because of its sample circumscribed with South Korean tourists using only one specific SNS. Since Western users prefer to use another SNS, other SNS should be investigated as well to confirm the results of the present study. Second, this study places emphasis on satisfaction with tourism experience from the perspective of perceived social support, positive emotions, and commitment. There are probably other determinant factors influencing satisfaction with tourism experience in the context of SNS use that should be investigated to provide a more complete understanding of the relationship between SNS use and satisfaction with tourism experience.

Therefore, we suggest that future researchers examine the theoretical research model provided in this study focusing on the representatives of various cultures using different SNS. Future research can also undertake a comparative study to investigate whether various SNS differ from each other in their contribution to the satisfaction with tourism experience. Moreover, the construct of perceived social support should be examined more scrupulously by future studies to determine its role in the relationships between SNS use and satisfaction with tourism experience. There may also be room for a more integrated model that includes factors determining SNS use and consequences of satisfaction with tourism experience affected by SNS use to provide a more clear and complete picture of the relationship between SNS use and satisfaction with tourism experience.

This research attempts to casually explore the relationships between SNS use and satisfaction with tourism experience by applying social influence theory and broaden-and-build theory of positive emotions as theoretical background to explain the concepts of commitment and positive emotions, respectively. In addition, this study aims to contribute theoretically to the existing literature by providing more knowledge about the role of perceived social support and positive emotions in the satisfaction with tourism experience and shedding light on the comprehension of the commitment in terms of the relationship between SNS use and satisfaction with tourism experience, as well as bring practical contributions to both tourism marketers and SNS managers.

Acknowledgments: This work was supported by the Ministry of Education of the Republic of Korea and the National Research Foundation of Korea (NRF-2016S1A3A2925146).

Author Contributions: Namho Chung and Inessa Tyan conceived and designed the experiments; Inessa Tyan performed the experiments and analyzed the data; and Namho Chung and Hee Chung Chung wrote and revised the paper. All of authors contributed to read and approved the final manuscript.

Conflicts of Interest: The authors declare no conflict of interest. The founding sponsors had no role in the design of the study; in the collection, analyses, or interpretation of data; in the writing of the manuscript, and in the decision to publish the results.

\section{References}

1. Xiang, Z.; Gretzel, U. Role of social media in online travel information search. Tour. Manag. 2010, 31, 179-188. [CrossRef]

2. Buhalis, D.; Law, R. Progress in information technology and tourism management: 20 years on and 10 years after the Internet-The state of eTourism research. Tour. Manag. 2008, 29, 609-623. [CrossRef]

3. Gretzel, U.; Kang, M.; Lee, W. Differences in consumer-generated media adoption and use: A cross-national perspective. J. Hosp. Leis. Mark. 2008, 17, 99-120. [CrossRef] 
4. Oh, H.J.; Ozkaya, E.; LaRose, R. How does online social networking enhance life satisfaction? The relationships among online supportive interaction, affect, perceived social support, sense of community, and life satisfaction. Comput. Hum. Behav. 2014, 30, 69-78. [CrossRef]

5. Akar, E.; Topçu, B. An examination of the factors influencing consumers' attitudes toward social media marketing. J. Internet Commer. 2011, 10, 35-67. [CrossRef]

6. Blackshaw, P. The Pocket Guide to Consumer Generated Media. 2005. Available online: http://www.clickz. com/showPage.html?page=3515576 (accessed on 11 November 2017).

7. Statista. 2017. Available online: https://www.statista.com/statistics/278414/number-of-worldwide-socialnetwork-users / (accessed on 20 October 2017).

8. Cheung, C.M.; Chiu, P.Y.; Lee, M.K. Online social networks: Why do students use facebook? Comput. Hum. Behav. 2011, 27, 1337-1343. [CrossRef]

9. Murray, K.E.; Waller, R. Social networking goes abroad. Int. Educ. 2007, 16, 56-59.

10. Li, D.C. Online social network acceptance: A social perspective. Internet Res. 2011, 21, 562-580. [CrossRef]

11. Kim, J.; Lee, J.E.R. The Facebook paths to happiness: Effects of the number of Facebook friends and self-presentation on subjective well-being. Cyberpsychol. Behav. Soc. Netw. 2011, 14, 359-364. [CrossRef] [PubMed]

12. Kalpidou, M.; Costin, D.; Morris, J. The relationship between Facebook and the well-being of undergraduate college students. Cyberpsychol. Behav. Soc. Netw. 2011, 14, 183-189. [CrossRef] [PubMed]

13. Vitak, J.; Ellison, N.B.; Steinfield, C. The ties that bond: Re-examining the relationship between Facebook use and bonding social capital. In Proceedings of the IEEE 44th Hawaii International Conference on System Sciences (HICSS), Kauai, HI, USA, 4-7 January 2011; pp. 1-10.

14. Leung, D.; Law, R.; Van Hoof, H.; Buhalis, D. Social media in tourism and hospitality: A literature review. J. Travel Tour. Mark. 2013, 30, 3-22. [CrossRef]

15. Dellarocas, $\mathrm{C}$. The digitization of word of mouth: Promise and challenges of online feedback mechanisms. Manag. Sci. 2003, 49, 1407-1424. [CrossRef]

16. Kang, M.; Schuett, M.A. Determinants of sharing travel experiences in social media. J. Travel Tour. Mark. 2013, 30, 93-107. [CrossRef]

17. Kim, J.; Tussyadiah, I.P. Social networking and social support in tourism experience: The moderating role of online self-presentation strategies. J. Travel Tour. Mark. 2013, 30, 78-92. [CrossRef]

18. Luo, Q.; Zhong, D. Using social network analysis to explain communication characteristics of travel-related electronic word-of-mouth on social networking sites. Tour. Manag. 2015, 46, 274-282. [CrossRef]

19. Milano, R.; Baggio, R.; Piattelli, R. The effects of online social media on tourism websites. In Information and Communication Technologies in Tourism 2011; Law, R., Fuchs, M., Ricci, F., Eds.; Springer: Berlin, Germany, 2011.

20. Park, N.; Kee, K.F.; Valenzuela, S. Being immersed in social networking environment: Facebook groups, uses and gratifications, and social outcomes. CyberPsychol. Behav. 2009, 12, 729-733. [CrossRef] [PubMed]

21. Huang, Y.; Basu, C.; Hsu, M.K. Exploring motivations of travel knowledge sharing on social network sites: An empirical investigation of US college students. J. Hosp. Mark. Manag. 2010, 19, 717-734. [CrossRef]

22. Mitas, O.; Yarnal, C.; Adams, R.; Ram, N. Taking a "peak" at leisure travelers' positive emotions. Leis. Sci. 2012, 34, 115-135. [CrossRef]

23. Kwortnik, R.J.; Ross, W.T. The role of positive emotions in experiential decisions. Int. J. Res. Mark. 2007, 24, 324-335. [CrossRef]

24. Yeung, C.W.; Wyer, R.S., Jr. Affect, appraisal, and consumer judgment. J. Consum. Res. 2004, 31, $412-424$. [CrossRef]

25. Filep, S.; Deery, M. Towards a Picture of Tourists' Happiness. Tour. Anal. 2010, 15, 399-410. [CrossRef]

26. Schmitt, B. Experiential marketing. J. Mark. Manag. 1999, 15, 53-67. [CrossRef]

27. Pühringer, S.; Taylor, A. A practitioner's report on blogs as a potential source of destination marketing intelligence. J. Vacat. Mark. 2008, 14, 177-187. [CrossRef]

28. Wang, D.; Park, S.; Fesenmaier, D.R. The role of smartphones in mediating the touristic experience. J. Travel Res. 2012, 51, 371-387. [CrossRef]

29. Kim, J.J.; Fesenmaier, D.R.; Johnson, S.L. The effect of feedback within social media in tourism experiences. In Design, User Experience, and Usability. Web, Mobile, and Product Design; Springer: Berlin/Heidelberg, Germany, 2013; pp. 212-220. 
30. Kelman, H.C. Compliance, identification, and internalization: Three processes of attitude change. J. Confl. Resolut. 1958, 2, 51-60. [CrossRef]

31. Chung, N.; Nam, K.; Koo, C. Examining Information Sharing in Social Networking Communities: Applying Theories of Social Capital and Attachment. Telemat. Inform. 2016, 33, 77-91. [CrossRef]

32. Jansen, B.J.; Zhang, M.; Sobel, K.; Chowdury, A. Twitter power: Tweets as electronic word of mouth. J. Am. Soc. Inf. Sci. Technol. 2009, 60, 2169-2188. [CrossRef]

33. Kotler, P.; Bowen, J.T.; Makens, J.C. Marketing for Hospitality and Tourism; Prentice Hall: Upper Saddle River, NJ, USA, 2010.

34. Pan, B.; MacLaurin, T.; Crotts, J.C. Travel blogs and the implications for destination marketing. J. Travel Res. 2007, 46, 35-45. [CrossRef]

35. Chu, S.C.; Kim, Y. Determinants of consumer engagement in electronic word-of-mouth (eWOM) in social networking sites. Int. J. Advert. 2011, 30, 47-75. [CrossRef]

36. Gretzel, U.; Sigala, M.; Xiang, Z.; Koo, C. Smart tourism: Foundations and developments. Electron. Mark. 2015, 25, 179-188. [CrossRef]

37. Burgess, S.; Sellitto, C.; Cox, C.; Buultjens, J. Trust perceptions of online travel information by different content creators: Some social and legal implications. Inf. Syst. Front. 2011, 13, 221-235. [CrossRef]

38. Yoo, K.H.; Lee, Y.; Gretzel, U.; Fesenmaier, D.R. Trust in travel-related consumer generated media. In Information and Communication Technologies in Tourism; Höpken, W., Gretzel, U., Law, R., Eds.; Springer: Berlin, Germany, 2009; pp. 49-59.

39. Kim, M.J.; Lee, C.K.; Bonn, M. The effect of social capital and altruism on seniors' revisit intention to social network sites for tourism-related purposes. Tour. Manag. 2016, 53, 96-107. [CrossRef]

40. Chung, N.; Han, H. The relationship among tourists' persuasion, attachment and behavioral changes in social media. Technol. Forecast. Soc. Chang. 2017, 123, 370-380. [CrossRef]

41. Hur, K.; Kim, T.T.; Karatepe, O.M.; Lee, G. An exploration of the factors influencing social media continuance usage and information sharing intentions among Korean travellers. Tour. Manag. 2017, 63, 170-178. [CrossRef]

42. Klein, H.J.; Molloy, J.C.; Brinsfield, C.T. Reconceptualizing workplace commitment to redress a stretched construct: Revisiting assumptions and removing confounds. Acad. Manag. Rev. 2012, 37, 130-151.

43. Zhou, T.; Li, H. Understanding mobile SNS continuance usage in China from the perspectives of social influence and privacy concern. Comput. Hum. Behav. 2014, 37, 283-289. [CrossRef]

44. Malhotra, Y.; Galletta, D. A multidimensional commitment model of volitional systems adoption and usage behavior. J. Manag. Inf. Syst. 2003, 22, 117-151. [CrossRef]

45. Chu, S.C.; Choi, S.M. Electronic word-of-mouth in social networking sites: A cross-cultural study of the United States and China. J. Glob. Mark. 2011, 24, 263-281. [CrossRef]

46. Dholakia, U.M.; Bagozzi, R.P.; Pearo, L.K. A social influence model of consumer participation in network-and small-group-based virtual communities. Int. J. Res. Mark. 2004, 21, 241-263. [CrossRef]

47. Lyubomirsky, S.; King, L.; Diener, E. The benefits of frequent positive affect: Does happiness lead to success? Psychol. Bull. 2005, 131, 803-855. [CrossRef] [PubMed]

48. Fredrickson, B.L. The role of positive emotions in positive psychology: The broaden-and-build theory of positive emotions. Am. Psychol. 2001, 56, 218-226. [CrossRef] [PubMed]

49. Rosenberg, E.L. Levels of analysis and the organization of affect. Rev. Gen. Psychol. 1998, 2, $247-270$. [CrossRef]

50. Frijda, N.H. The Laws of Emotion; Routledge: London, UK, 2007.

51. Gibson, H.; Willming, C.; Holdnak, A. “We're Gators... Not Just Gator Fans": Serious Leisure and University of Florida Football. J. Leis. Res. 2002, 34, 397-425.

52. Singh, S. Love, anthropology and tourism. Ann. Tour. Res. 2002, 29, 261-264. [CrossRef]

53. Tugade, M.M.; Fredrickson, B.L. Regulation of positive emotions: Emotion regulation strategies that promote resilience. J. Happiness Stud. 2007, 8, 311-333. [CrossRef]

54. Lin, K.Y.; Lu, H.P. Why people use social networking sites: An empirical study integrating network externalities and motivation theory. Comput. Hum. Behav. 2011, 27, 1152-1161. [CrossRef]

55. Cobb, S. Social support as a moderator of life stress. Psychosom. Med. 1976, 38, 300-314. [CrossRef] [PubMed]

56. Mikal, J.P.; Grace, K. Against abstinence-only education abroad: Viewing Internet use during study abroad as a possible experience enhancement. J. Stud. Int. Educ. 2012, 16, 287-306. [CrossRef] 
57. Caplan, R.D. Social Support, Person-environment Fit, and Coping. In Mental Health and the Economy; Ferman, L.A., Gordus, J.P., Eds.; W E. Upjohn Institute for Employment Research: Kalamazoo, MI, USA, 1979; pp. 89-138.

58. Sherbourne, C.D.; Stewart, A.L. The MOS social support survey. Soc. Sci. Med. 1991, 32, 705-714. [CrossRef]

59. Gottlieb, B.H.; Bergen, A.E. Social support concepts and measures. J. Psychosom. Res. 2010, 69, 511-520. [CrossRef] [PubMed]

60. Huang, J.; Hsu, C.H. The impact of customer-to-customer interaction on cruise experience and vacation satisfaction. J. Travel Res. 2010, 49, 79-92. [CrossRef]

61. Klooster, E.; Go, F. Leveraging computer mediated communication for social support in educational travel. In Information and Communication Technologies in Tourism; Hitz, M., Sigala, M., Murphy, J., Eds.; Springer: Berlin, Germany, 2006.

62. Brent Ritchie, J.R.; Wing Sun Tung, V.; Ritchie, R.J. Tourism experience management research: Emergence, evolution and future directions. Int. J. Contemp. Hosp. Manag. 2011, 23, 419-438. [CrossRef]

63. Trauer, B.; Ryan, C. Destination image, romance and place experience-An application of intimacy theory in tourism. Tour. Manag. 2005, 26, 481-491. [CrossRef]

64. Su, L.; Huang, S.; Chen, X. Effects of Service Fairness and Service Quality on Tourists' Behavioral Intentions and Subjective Well-Being. J. Travel Tour. Mark. 2015, 32, 290-307. [CrossRef]

65. Neuhofer, B.; Buhalis, D.; Ladkin, A. A Typology of technology-enhanced tourism experiences. Int. J. Tour. Res. 2014, 16, 340-350. [CrossRef]

66. Gretzel, U.; Jamal, T. Conceptualizing the creative tourist class: Technology, mobility, and tourism experiences. Tour. Anal. 2009, 14, 471-481. [CrossRef]

67. Binkhorst, E.; Den Dekker, T. Agenda for co-creation tourism experience research. J. Hosp. Mark. Manag. 2009, 18, 311-327. [CrossRef]

68. Uriely, N. The tourist experience: Conceptual developments. Ann. Tour. Res. 2005, 32, 199-216. [CrossRef]

69. Lewis, S.; Pea, R.; Rosen, J. Beyond participation to co-creation of meaning: Mobile social media in generative learning communities. Soc. Sci. Inf. 2010, 49, 351-369. [CrossRef]

70. Tussyadiah, I.P.; Fesenmaier, D.R. Mediating tourist experiences: Access to places via shared videos. Ann. Tour. Res. 2009, 36, 24-40. [CrossRef]

71. Ellison, N.B.; Steinfield, C.; Lampe, C. The benefits of Facebook "friends": Social capital and college students' use of online social network sites. J. Comput. Med. Commun. 2007, 12, 1143-1168. [CrossRef]

72. Hampton, K.; Goulet, L.S.; Rainie, L.; Purcell, K. Social Networking Sites and Our Lives; Pew Research Center's Internet \& Americal Life Project: Washington, DC, USA, 2011; Volume 2012.

73. Wang, Y.; Fesenmaier, D.R. Towards understanding members' general participation in and active contribution to an online travel community. Tour. Manag. 2004, 25, 709-722. [CrossRef]

74. Parra-López, E.; Bulchand-Gidumal, J.; Gutiérrez-Taño, D.; Díaz-Armas, R. Intentions to use social media in organizing and taking vacation trips. Comput. Hum. Behav. 2011, 27, 640-654. [CrossRef]

75. Sigala, M. Measuring customer value in online collaborative trip planning processes. Mark. Intell. Plan. 2010, 28, 418-443. [CrossRef]

76. Hudson, S.; Roth, M.S.; Madden, T.J.; Hudson, R. The effects of social media on emotions, brand relationship quality, and word of mouth: An empirical study of music festival attendees. Tour. Manag. 2015, 47, 68-76. [CrossRef]

77. Kang, Y.S.; Lee, H. Understanding the role of an IT artifact in online service continuance: An extended perspective of user satisfaction. Comput. Hum. Behav. 2010, 26, 353-364. [CrossRef]

78. Wang, Y.; Fesenmaier, D.R. Modeling participation in an online travel community. J. Travel Res. 2004, 42, 261-270. [CrossRef]

79. Chung, J.Y.; Buhalis, D. A study of online travel community and Web 2.0: Factors affecting participation and attitude. In Information and Communication Technologies in Tourism 2008; Höpken, W., Gretzel, U., Eds.; Springer: Berlin, Germany, 2008; pp. 267-278.

80. Baker, R.K.; White, K.M. Predicting adolescents' use of social networking sites from an extended theory of planned behaviour perspective. Comput. Hum. Behav. 2010, 26, 1591-1597. [CrossRef]

81. Schaefer, C.; Coyne, J.C.; Lazarus, R.S. The health-related functions of social support. J. Behav. Med. 1981, 4, 381-406. [CrossRef] [PubMed] 
82. Neal, J.D.; Uysal, M.; Sirgy, M.J. The effect of tourism services on travelers' quality of life. J. Travel Res. 2007, 46, 154-163. [CrossRef]

83. Young, K.W. Social support and life satisfaction. Int. J. Psychosoc. Rehabilit. 2006, 10, 155-164.

84. Greenglass, E.R.; Fiksenbaum, L. Proactive coping, positive affect, and well-being: Testing for mediation using path analysis. Eur. Psychol. 2009, 14, 29-39. [CrossRef]

85. Köbler, F.; Riedl, C.; Vetter, C.; Leimeister, J.M.; Krcmar, H. Social Connectedness on Facebook: An explorative study on status message usage. In Proceedings of the 16th Americas Conference on Information Systems, Lima, Peru, 12-15 August 2010.

86. Klingensmith, C.L. 500 Friends and Still Friending: The Relationship between Facebook and College Students' Social Experiences. 2010. Available online: http://digitalcommons.macalester.edu/psychology_honors/22/ (accessed on 11 November 2017).

87. Vieno, A.; Santinello, M.; Pastore, M.; Perkins, D.D. Social support, sense of community in school, and self-efficacy as resources during early adolescence: An integrative model. Am. J. Community Psychol. 2007, 39, 177-190. [CrossRef] [PubMed]

88. Manago, A.M.; Taylor, T.; Greenfield, P.M. Me and my 400 friends: The anatomy of college students' Facebook networks, their communication patterns, and well-being. Dev. Psychol. 2012, 48, 369-380. [CrossRef] [PubMed]

89. Toma, C.L. Affirming the self through online profiles: Beneficial effects of social networking sites. In Proceedings of the SIGCHI Conference on Human Factors in Computing Systems, Atlanta, GA, USA, 10-15 April 2010; pp. 1749-1752.

90. Bigné, J.E.; Andreu, L. Emotions in segmentation: An empirical study. Ann. Tour. Res. 2004, 31, 682-696. [CrossRef]

91. Clore, G.L.; Huntsinger, J.R. How emotions inform judgment and regulate thought. Trends Cogn. Sci. 2007, 11, 393-399. [CrossRef] [PubMed]

92. Wang, N. Rethinking authenticity in tourism experience. Ann. Tour. Res. 1999, 26, 349-370. [CrossRef]

93. Kozinets, R.V. E-tribalized marketing?: The strategic implications of virtual communities of consumption. Eur. Manag. J. 1999, 17, 252-264. [CrossRef]

94. Pagani, M.; Hofacker, C.F.; Goldsmith, R.E. The influence of personality on active and passive use of social networking sites. Psychol. Mark. 2011, 28, 441-456. [CrossRef]

95. Venkatesh, V. Determinants of perceived ease of use: Integrating control, intrinsic motivation, and emotion into the technology acceptance model. Inf. Syst. Res. 2000, 11, 342-365. [CrossRef]

96. Hsu, C.L.; Lin, J.C.C. Acceptance of blog usage: The roles of technology acceptance, social influence and knowledge sharing motivation. Inf. Manag. 2008, 45, 65-74. [CrossRef]

97. Lim, S.; Cha, S.Y.; Park, C.; Lee, I.; Kim, J. Getting closer and experiencing together: Antecedents and consequences of psychological distance in social media-enhanced real-time streaming video. Comput. Hum. Behav. 2012, 28, 1365-1378. [CrossRef]

98. Tussyadiah, I.P.; Zach, F.J. The role of geo-based technology in place experiences. Ann. Tour. Res. 2012, 39, 780-800. [CrossRef]

99. Kelman, H.C. Processes of opinion change. Public Opin. Q. 1961, 25, 57-78. [CrossRef]

100. Ahuja, M.K.; Thatcher, J.B. Moving beyond intentions and toward the theory of trying: Effects of work environment and gender on post-adoption information technology use. MIS Q. 2005, 29, 427-459.

101. Gerbing, D.W.; Anderson, J.C. An updated paradigm for scale development incorporating unidimensionality and its assessment. J. Mark. Res. 1988, 25, 186-192. [CrossRef]

102. Fornell, C.; Larcker, D.F. Evaluating structural equation models with unobservable variables and measurement error. J. Mark. Res. 1981, 18, 39-50. [CrossRef]

103. Hair, J.F.; Black, W.C.; Babin, H.J.; Anderson, R.E. Multivariate Data Analysis, 7th ed.; Prentice Hall: Upper Saddle River, NJ, USA, 2010.

104. Bagozzi, R.P.; Yi, Y. On the evaluation of structural equation models. J. Acad. Mark. Sci. 1988, $16,74-94$. [CrossRef]

105. Gefen, D.; Straub, D. A practical guide to factorial validity using PLS-Graph: Tutorial and annotated example. Commun. Assoc. Inf. Syst. 2005, 16, 91-109.

106. Choi, S.M.; Kim, Y.; Sung, Y.; Sohn, D. Bridging or Bonding? A cross-cultural study of social relationships in social networking sites. Inf. Commun. Soc. 2011, 14, 107-129. [CrossRef] 
107. Utz, S.; Beukeboom, C.J. The role of social network sites in romantic relationships: Effects on jealousy and relationship happiness. J. Comput. Med. Commun. 2011, 16, 511-527. [CrossRef]

108. De Choudhury, M.; Counts, S.; Horvitz, E. Predicting postpartum changes in emotion and behavior via social media. In Proceedings of the SIGCHI Conference on Human Factors in Computing Systems, Paris, France, 27 April-2 May 2013; ACM: New York, NY, USA, 2013; pp. 3267-3276.

109. Prayag, G.; Hosany, S.; Odeh, K. The role of tourists' emotional experiences and satisfaction in understanding behavioral intentions. J. Destin. Mark. Manag. 2013, 2, 118-127. [CrossRef]

110. Grappi, S.; Montanari, F. The role of social identification and hedonism in affecting tourist re-patronizing behaviours: The case of an Italian festival. Tour. Manag. 2011, 32, 1128-1140. [CrossRef]

111. Palau-Saumell, R.; Forgas-Coll, S.; Sánchez-García, J.; Prats-Planagumà, L. Tourist Behavior Intentions and the Moderator Effect of Knowledge of UNESCO World Heritage Sites the Case of La Sagrada Família. J. Travel Res. 2013, 52, 364-376. [CrossRef]

112. Hosany, S.; Prayag, G. Patterns of tourists' emotional responses, satisfaction, and intention to recommend. J. Bus. Res. 2013, 66, 730-737. [CrossRef]

(C) 2017 by the authors. Licensee MDPI, Basel, Switzerland. This article is an open access article distributed under the terms and conditions of the Creative Commons Attribution (CC BY) license (http://creativecommons.org/licenses/by/4.0/). 